Laporan Kasus

\title{
Keberhasilan jabir bebas forearm dan jabir forehead paramedian pada rekonstruksi defek wajah luas
}

\author{
Lina Marlina, Yussy Afriani Dewi, Irra Rubianti, Shinta Fitri Boesoirie \\ Departemen Ilmu KesehatanTelinga Hidung Tenggorok - Bedah Kepala Leher \\ Fakultas Kedokteran Universitas Padjadjaran/Rumah Sakit Hasan Sadikin \\ Bandung
}

\begin{abstract}
ABSTRAK
Latar belakang: Penutupan defek wajah yang luas dengan jabir bebas forearm dan jabir forehead paramedian merupakan salah satu pilihan pada pasien pasca eksisi luas dan pemberian radioterapi akibat keganasan kepala leher. Tetapi cara ini bukan merupakan pilihan yang utama, meskipun memiliki tingkat keberhasilan yang baik, khususnya pasca radioterapi. Tujuan: Kasus ini diajukan untuk memperlihatkan keberhasilan penutupan defek wajah yang luas dengan jabir bebas forearm, jabir forehead paramedian pasca eksisi luas dan radioterapi pada kasus karsinoma sel basal. Laporan kasus: Dilaporkan seorang perempuan 68 tahun dengan karsinoma sel basal yang dilakukan tindakan eksisi luas dan radioterapi. Penatalaksanaan: Setelah 6 bulan pasca radioterapi, dilakukan penutupan defek dengan menggunakan jabir bebas forearm, dan jabir forehead paramedian yang digunakan sebagai pengganti mukosa hidung serta dilakukan anastomosis radial forearm. Bagian dahi ditutup dengan full thickness skin graft (FTSG) yang diambil dari regio abdominal pasien. Kesimpulan: Jabir bebas forearm dan jabir forehead paramedian merupakan salah satu alternatif untuk rekonstruksi defek luas pada daerah kepala leher sesudah radioterapi.
\end{abstract}

Kata kunci: Jabir bebas forearm, jabir forehead paramedian, karsinoma sel basal, radioterapi, eksisi luas

\section{ABSTRACT}

Background: Paramedian forehead flap and radial forearm free flap is one option for reformation of excessive defect caused by tumor extirpation and radiotherapy in head and neck cancer, but not the main option in head neck reconstruction. In some certain condition, it has a better success rate than other flap techniques, especially in postradiation patients on facial region. Purpose: To present evidence based case report in order to show the result of reconstruction in a patient with basal cell carcinoma who underwent wide excision with paramedian forehead flap, radial forearm free flap and radiotherapy. Case report: We reported one case, a 68 years old woman who had basal cell carcinoma and underwent wide excision and radiotherapy. Management: Six months later, we performed reconstructive surgery to close the forehead defect by reverse paramedian forehead flap, and replacing the nasal mucosa with radial forearm anastomosis, on the forehead covered with a full thickness skin graft (FTSG) taken from abdominal region of the patient. Conclusion: Radial forearm and paramedian forehead flap can be considered as an alternative for reconstruction of wide defect of the head pasca radiotherapy.

Keywords: Radial forearm flap, and paramedian forehead flap, basal cell carcinoma, radiotherapy, wide excision

Alamat korespondensi: Lina Marlina, Departemen Ilmu Kesehatan Telinga Hidung Tenggorok-Bedah Kepala Leher, Fakultas Kedokteran Universitas Padjadjaran/RumahSakit Hasan Sadikin, Bandung, e-mail: hendrika.lina@gmail.com. 


\section{PENDAHULUAN}

Jabir adalah suatu unit jaringan yang dipindahkan dari satu area (donor site) ke area yang lain (recipient site) dengan masih mempertahankan sistem aliran darahnya sendiri. Berbagai jenis jabir dan skema klasifikasi jabir dapat ditandai dengan bagianbagian komponennya (kulit, muskulokutaneous, osseokutaneus), berhubungan dengan lokasi defek (lokal, regional, atau jauh), sifat suplai darah (random dan aksial), atau dengan gerakan jabir untuk mengisi defek (misalnya, kemajuan, poros, transposisi). ${ }^{1,2}$

Jabir bebas melibatkan transplantasi jaringan menggunakan operasi mikrovaskuler. Transfer jaringan bebas mikrovaskuler adalah teknik rekonstruksi di mana unit jaringan terpisah dari suplai darah induk dan pindah dari satu bagian tubuh ke lokasi yang baru. Jaringan donor memiliki arteri dan vena yang diidentifikasi dapat direanastomosis dengan pembuluh penerima, sehingga dapat terbentuk kembali aliran darah. Potensi reinnervation sensorik juga ada melalui reanastomosis saraf kulit. ${ }^{3}$ Operasi jabir bebas memerlukan keahlian khusus terutama keahlian bedah mikrovaskular. Insidens operasi jabir bebas di salah satu rumah sakit sentra pendidikan di Amerika selama 10 tahun (Januari 2001-31 Desember 2010) mencapai 450 kasus atau kurang lebih 45 kasus per tahun. ${ }^{4}$ Salah satu rumah sakit di India, melakukan operasi jabir bebas pada kepala dan leher sebanyak 22 kasus dalam 6 bulan. ${ }^{5}$ Rerata insidensinya terjadi pada usia 50-60 tahun. ${ }^{6}$

Tujuan dasar dari rekonstruksi kepala leher adalah untuk menggantikan jaringan lunak dan defek pada tulang dengan jaringan yang serupa, memulihkan dan mengembalikan fungsinya, serta optimal dari sisi kosmetik. ${ }^{7}$ Rekonstruksi wajah dengan jabir bebas memerlukan kecocokan warna kulit yang optimal, ukuran jabir yang cukup terhadap ukuran defek, dan panjang pedikel yang cukup. ${ }^{8}$ Kata jabir pada jabir bebas diartikan bahwa jaringan, bersama dengan pasokan darah, terlepas dari lokasi asli (“donor") dan kemudian dipindahkan ke lokasi lain ("bed/penerima"). Berbeda dengan jabir "pedicled", yaitu jaringan yang tersisa melekat pada situs donor dan hanya dialihkan ke lokasi baru dengan menjaga pedikel utuh sebagai saluran untuk memasok jaringan. ${ }^{9}$ Berbagai jenis jaringan dapat ditransfer sebagai jabir bebas termasuk kulit, lemak, otot, saraf, tulang, atau kombinasi. Pasien kemudian dievaluasi berdasarkan faktor yang dapat memengaruhi kesembuhan, seperti ukuran luas defek dan jenis jaringan, lokasi donor, lamanya operasi, kemampuan operator, dan faktor status kesehatan pasien secara menyeluruh. Dibutuhkan keahlian khusus pada operasi mikrovaskular. ${ }^{10}$ Ekstermitas donor harus diberi tanda agar ahli anestesi tidak melakukan pemasangan infus pada area tersebut. Obat-obat pra-medikasi seperti antibiotik, steroid, dan obat pra-medikasi lain harus terukur dan indikatif. Untuk anestesi infiltasi digunakan lidokain 1\% tanpa epinefrin. Penggunaan antikoagulasi seperti heparin dan plasma ekspander digunakan untuk mengurangi kemungkinan trombosis vaskular. Heparin 5000 unit dapat digunakan selama pada bagian akhir dari anastomosis vena dan dilanjutkan sampai prothrombin pime sekitar 1,5 kali dari nilai normal. Aspirin 5-10 tablet per hari. Pemberian dextran dapat diberikan secara kontinu atau serial melalui infus. ${ }^{11,12}$

Pada kasus ini digunakan penggunaan jabir bebas dan jabir dahi paramedian karena pada kasus pasca radioterapi akan memberikan vaskularisasi lebih baik dengan jabir yang luas, sedangkan kekurangannya adalah memerlukan donor yang cukup luas sehingga menyebabkan sulitnya perawatan luka dan memperpanjang waktu rawat. Jabir lepas (jabir bebas) merupakan jabir yang bagian pangkalnya beserta pembuluh darah arteri dan vena diputuskan, kemudian dipindah dan ditanam pada defek dengan menyambung pembuluh darah. ${ }^{13}$ Chepeha $\mathrm{DB}^{14}$ pada penelitiannya memperlihatkan angka keberhasilan penggunaan jabir bebas forearm pada defek wajah yang luas mencapai $89,8 \%$. Yap et a $\mathrm{l}^{15}$ melaporkan komplikasi pasca jabir bebas forearm sekitar 9,2\%-51\%. 
Berdasarkan sistem perdarahannya, jabir dibagi atas 2 tipe yaitu pola jabir aksial (axial pattern flap) dan pola jabir acak (random pattern flap). Jabir aksial merupakan jabir yang mempunyai sumber perdarahan dari pembuluh darah yang dikenal secara anatomis, contohnya jabir dahi. Pola jabir acak merupakan jabir yang mempunyai sumber perdarahan yang tidak dikenal secara anatomis. Kelangsungan hidup jabir tergantung pada jaringan pembuluh darah kecil. Ukuran jabir acak ini terbatas, dan biasanya digunakan sebagai jabir lokal untuk menutupi ukuran luka kecil. ${ }^{15}$

Berdasarkan sumber perdarahannya, jabir dibagi atas beberapa tipe yaitu jabir kulit (cutaneus flap) dan jabir arteri. Jabir kulit mendapatkan sumber perdarahan dari pembuluh kapiler kulit, yaitu pleksus dermal dan subdermal, tergantung pada tekanan pleksus kapiler. Jabir arteri mendapat sumber perdarahan langsung dari arteri kutaneus menurut aksis longitudinal. Jabir arteri terbagi atas beberapa tipe yaitu jabir arteri peninsular dan jabir arteri pulau. Jabir arteri peninsular merupakan jabir yang pangkalnya terdiri dari kulit dan jaringan subkutis, di dalamnya berjalan arteri dan vena kutaneus yang langsung memberikan perdarahan pada jabir tersebut. Jabir arteri pulau (island flap), merupakan jabir yang bagian pangkalnya tidak dihubungkan oleh kulit, tetapi oleh otot dengan vaskularisasinya, atau hanya oleh arteri dan vena yang memberikan pendarahan pada jabir tersebut. ${ }^{15}$

Tujuan penulisan laporan kasus ini adalah untuk mengetahui tingkat keberhasilan penggunaan jabir bebas forearm dan jabir forehead paramedian pada rekonstruksi defek wajah luas.

\section{LAPORAN KASUS}

Seorang wanita berusia 58 tahun, datang ke Poliklinik THT-KL Rumah Sakit Hasan Sadikin pada tanggal 11 November 2013 dengan keluhan utama terdapat luka di hidung yang susah sembuh sejak 4 tahun yang lalu. Pada anamnesis didapatkan permulaan lesi sebagai bercak hitam yang terasa gatal dan mudah berdarah. Semakin lama luka tersebut semakin membesar menjalar ke bagian pinggir dasar hidung dan mata, sehingga membentuk gaung dan tidak sembuh setelah diobati. Penglihatan mata sebelah kiri dirasakan tidak dapat melihat sama sekali. Penderita tidak mengeluhkan adanya benjolan di leher, ketiak, serta penurunan berat badan. Riwayat mimisan, suara serak, suara sengau, sesak nafas, dan sulit menelan tidak ada.

Pada pemeriksaan fisik didapatkan keadaan umum baik dan dalam batas normal. Status lokalis daerah hidung terdapat ulkus dari puncak sampai ke dasar rongga hidung ukuran $5 \times 3 \times 7 \mathrm{~cm}$ dan mudah berdarah, lain-lain dalam batas normal.

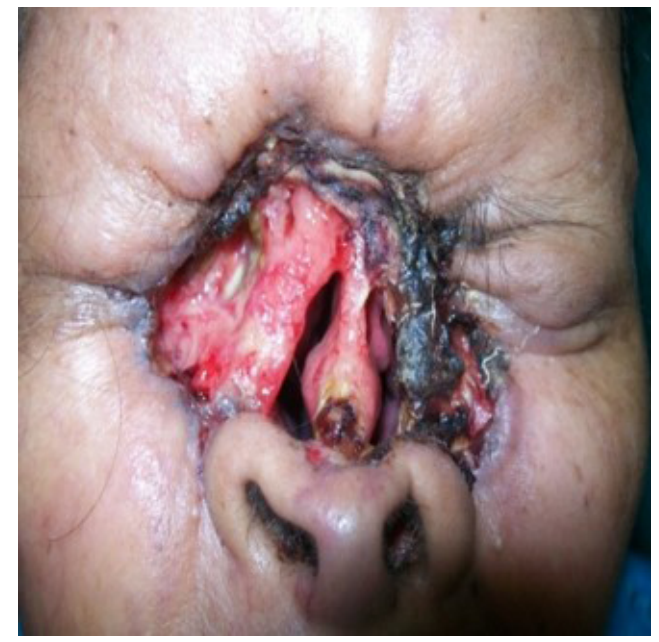

Gambar 1. Gambaran klinis penderita

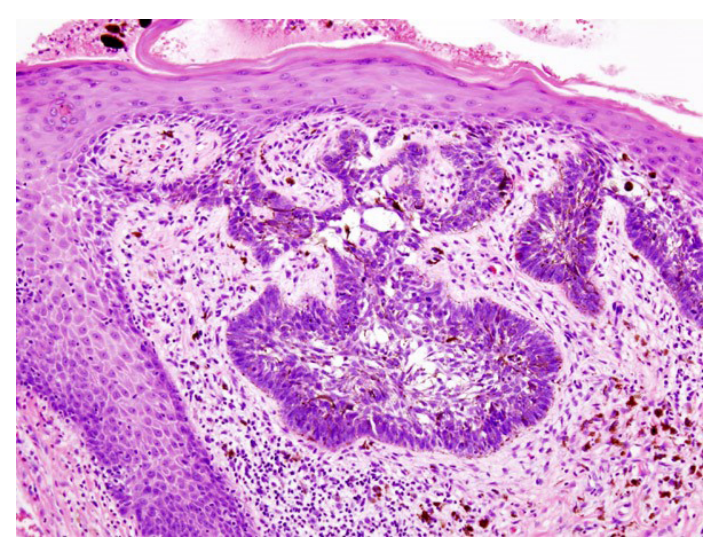

Gambar 2. Histopatologi karsinoma sel basal 

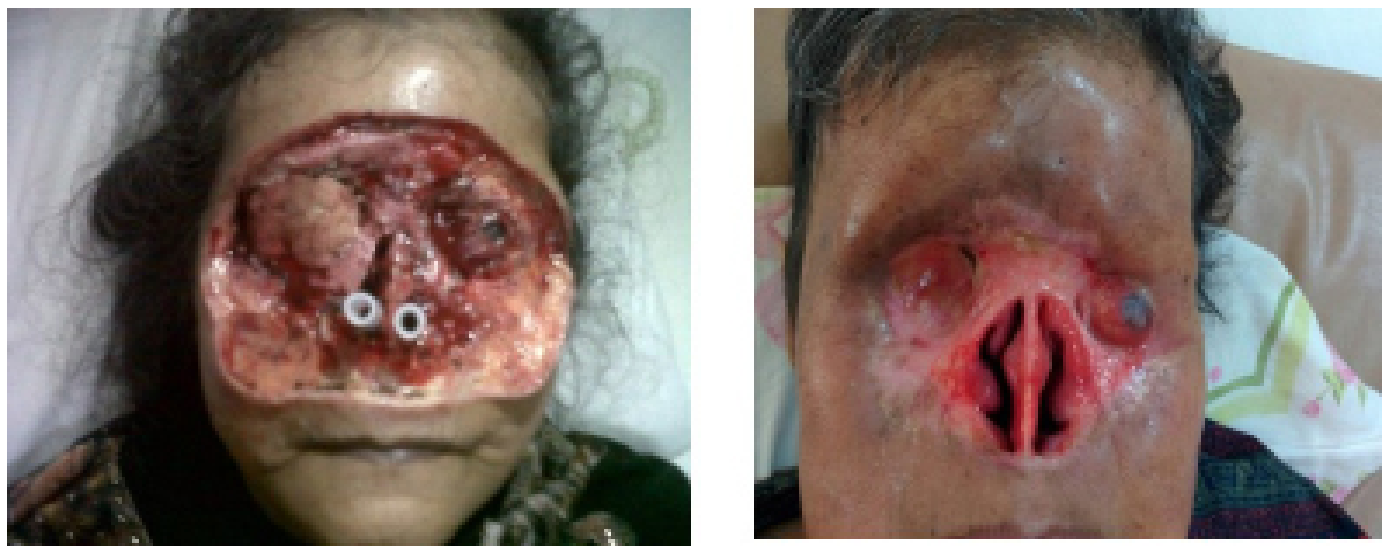

Gambar 3. Pasca operasi eksisi luas (kiri) dan enam bulan pasca radioterapi (kanan)

Pada pemeriksaan penunjang berupa nasoendoskopi, laboratorium, dan foto polos dada dalam batas normal. Hasil pemeriksaan histopatologis dari daerah dorsum nasi didapatkan tumor berbentuk pulau yang tumbuh infiltratif. Sel tumor tersusun menyerupai kelenjar dan mensekresi musin. Inti sel tumor berbentuk basaloid, dan pada bagian tepi menyusun gambaran palisade. Gambaran histologis sesuai dengan karsinoma sel basal jenis solid dengan pertumbuhan infiltratif.

Diagnosis yang ditegakkan adalah basalioma di hidung yang meluas sampai ke dahi dan mata. Pasien direncanakan untuk dilakukan tindakan eksisi luas yang dilanjutkan dengan pemeriksaan potong beku dan radioterapi. Massa tumor diangkat mulai dari bagian tepi, dekat kantus medial bola mata kiri dan dilakukan enukleasi bola mata kanan, mengikuti tepi massa garis wajah sampai ke ala nasi kiri, ke arah kaudal dan seluruh ala nasi kanan dan kiri sampai dasar kolumela dan sebagian septum anterior. Hasil pemeriksaan potong beku didapatkan seluruh batas sediaan bebas dari tumor. Luka operasi ditutup dengan kassa steril.

Pada tanggal 4 Januari 2014, hasil pemeriksaan histopatologis didapatkan sediaan berasal dari hidung terdiri atas jaringan kulit dengan epidermis atrofi dan ulseratif. Pada dermis tampak pulau sel tumor padat dengan ukuran sedang, inti bulat dan lonjong, hiperkromatik dan sebagian vesikuler. Pada bagian tepi massa tumor tersusun sel seperti pagar. Di beberapa tempat sel tumor mengalami degenerasi kistik berisi mukus dan sel mitosis. Stroma terdiri atas jaringan ikat padat. Semua batas sayatan dan dasar sayatan bebas sel tumor. Disimpulkan bahwa karsinoma sel basal jenis solid dan pola pertumbuhan infiltratif sklerosing. Penatalaksanaan selanjutnya dilakukan radioterapi pada tanggal 20 Januari 2014.
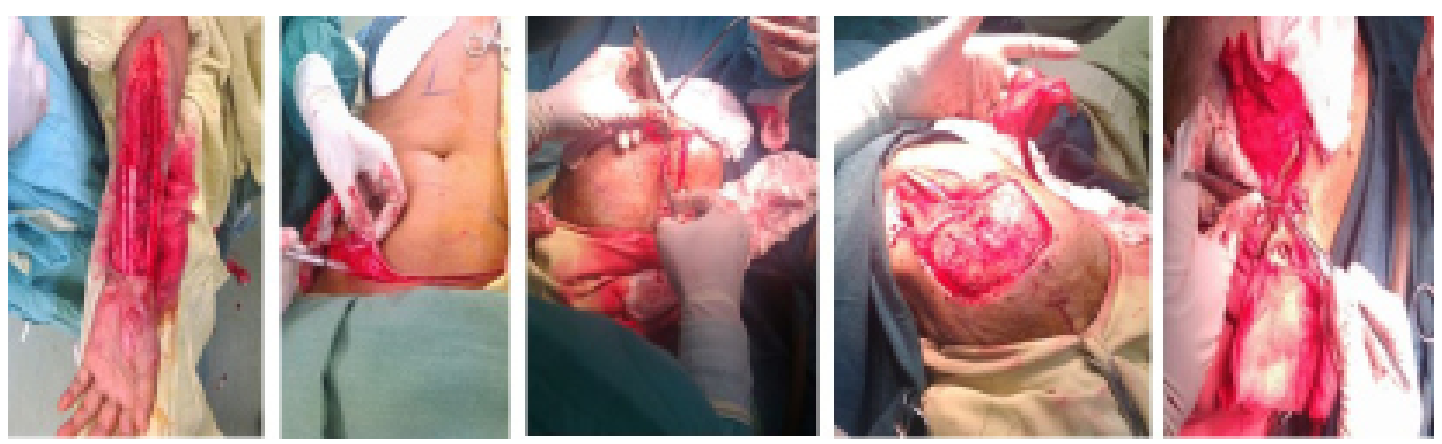

Gambar 4. Pasca operasi eksisi luas (kiri) dan enam bulan pasca radioterapi (kanan) 


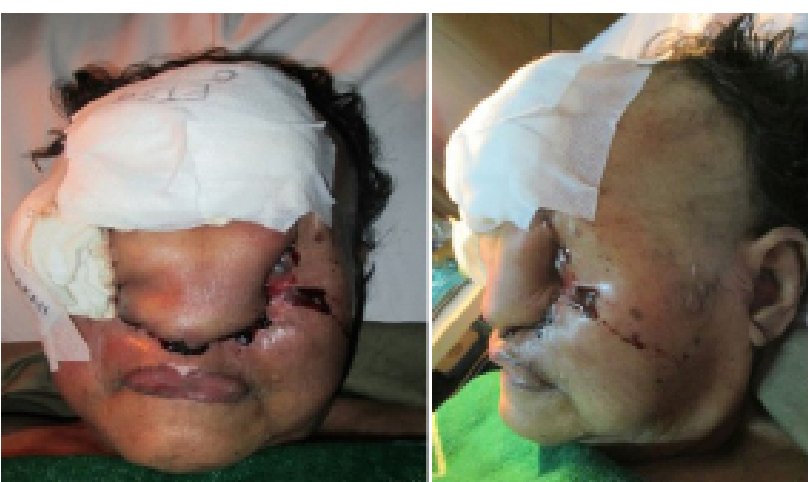

Gambar 5. Satu hari pasca-operasi

Radioterapi dilakukan sebanyak 33 kali dengan lokasi penyinaran lokoregional dosis $6600 \mathrm{rad}$, kemudian direncanakan untuk dilakukan penutupan defek setelah 6 bulan pasca radioterapi tersebut.

Pada tanggal 4 Agustus 2014, dilakukan operasi penutupan defek. Diambil kartilago dari kosta 7 kiri yang dibentuk sebagai pengganti os nasal, untuk tandur kulit bagian dalam hidung digunakan jabir dahi paramedian yang ditransposisikan. Selanjutnya, untuk defek dahi yang sudah ditransposisikan, ditutup dengan full thickness skin graft (FTSG), yang diambil dari regio abdominal pasien. Kemudian luka FTSG pada regio abdominal ditutup dengan jahitan primer. Tandur ditutup dengan balut tekan bertali (tie over), penjahitan dengan vicril 4-0 dan prolene 4-0.

Jabir radial forearm berasal dari forearm kiri yaitu yang diperdarahi cabang dari a. radialis dan v. antebrakialis, kemudian dilakukan penempatan jabir tersebut pada regio zigoma dekstra. Feeding arteri dan vena atau pedikel pada zigoma yang berasal dari a. zigomatikorbita dekstra dan v. temporalis superfisial dekstra dianastomosis dengan pembuluh darah jabir radial forearm tersebut.

Perawatan pasca operasi selama 2 minggu di bangsal dengan memposisikan kepala lebih tinggi 45 derajat. Daerah tandur hidung dihangati dengan sinar lampu sorot 10 Watt jarak 30-40 cm dari jabir, tekanan darah sistolik pertahankan di atas $100 \mathrm{mmHg}$, pengobatan yang diberikan ceftriaxone $1 \times 2$ gr injeksi

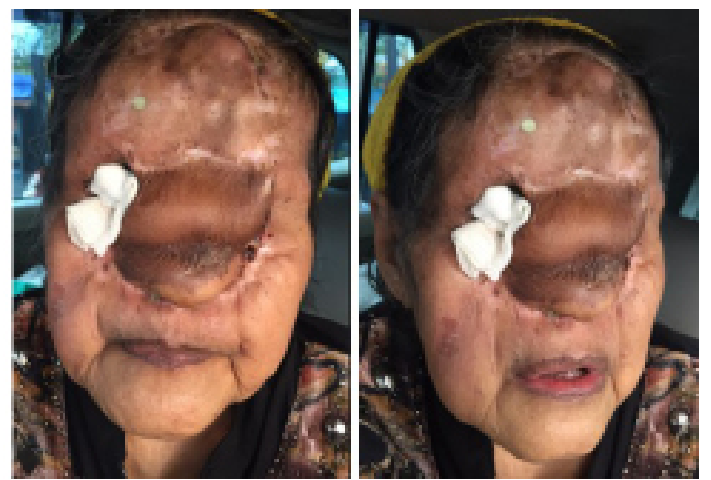

Gambar 6. Enam bulan pasca tandur kulit

selama 7 hari, aspirin 2x80 mg per oral selama 10 hari.

Pada tanggal 9 Agustus 2014, pada hari kelima pasca operasi, pengangkatan tie over, serta sebagian jahitan pada tandur, tampak tandur tumbuh. Tanggal 11 Agustus 2014 hari ketujuh pasca operasi dilakukan pengangkatan seluruh jahitan pada tandur, Tampak tandur tumbuh dan luka di daerah donor yaitu abdominal telah menutup dan kering. Tanggal 17 Agustus 2014, empat belas hari pasca operasi kondisi tandur baik, tidak pucat, tidak terdapat hematoma, dan tidak terdapat pus.

\section{DISKUSI}

Operasi jabir bebas memerlukan keahlian khusus terutama keahlian bedah mikrovaskular. Insidensi jumlah operasi jabir bebas di Amerika selama tahun 2001-2010 sebanyak 450 kasus, di India sebanyak 22 kasus dalam 6 bulan. ${ }^{11}$ Rerata insidensinya dengan usia 50-60 tahun. Departemen Bedah Plastik Rumah Sakit Cipto Mangunkusumo (RSCM) Jakarta dalam 1 tahun (2009-2010) melakukan operasi jabir bebas sebanyak 17 kasus, 6 diantaranya adalah jabir bebas pada daerah kepala dan leher. Insidensi laki-laki lebih banyak dari pada perempuan (7:3). Basalioma merupakan jenis keganasan kulit di daerah hidung yang sering dijumpai. Martini ${ }^{12}$ dalam penelitiannya melaporkan $90 \%$ jumlah kasus keganasan di hidung adalah jenis basalioma, 9\% karsinoma sel skuamosa, dan $1 \%$ tipe campuran termasuk melanoma. 
Faktor prediposisi timbulnya basalioma pada kasus ini adalah pemaparan lama terhadap sinar matahari. Hal ini sesuai dengan pekerjaan pasien yaitu bertani. Gordon dan Silverstone seperti yang dikuti oleh Brunicardi et al ${ }^{13}$ dari penelitiannya menyimpulkan bahwa lebih dari 90\% keganasan di kulit terdapat pada daerah tubuh yang sering terpapar oleh sinar matahari, Selain itu, insiden keganasan di kulit lebih sering pada orang yang bekerja di luar rumah, Kadar pigmentasi kulit juga berpengaruh terhadap insidens dan prevalensi keganasan kulit. Waktu pemaparan yang lama terhadap sinar ultraviolet akan memicu terjadinya keganasan kulit.

Hidung merupakan tempat predileksi tersering terjadinya basalioma, yaitu $90 \%$ kasus. Hal ini berhubungan erat dengan posisi hidung yang mudah terpapar oleh sinar matahari. Hidung merupakan daerah penyebaran pada masa fusi embrional, sehingga merupakan daerah yang berisiko tinggi terjadinya keganasan di samping telinga. ${ }^{14}$

Pemindahan mikrovaskular jaringan bebas (microvascular free-tissue) diperkenalkan sebagai suatu teknik untuk merekonstruksi defek yang tidak dapat diperbaiki selain dengan rekonstruksi. Kemampuan dari revaskularisasi jaringan dan lamanya operasi menjadi perhatian pertama dari teknik ini. Jabir pedikel regional dibayangi teknik pemindahan mikrovaskular jaringan bebas. Secara teknik regional jabir lebih mudah, hanya membutuhkan satu tim operasi, dan menyiapkan jaringan yang tidak mengalami radiasi. Mikrovaskuler rekonstruksi terus berkembang. Digambarkan bahwa setiap tahun lebih banyak lagi daerah atau tempat untuk teknik ini, dan fleksibilitas dari setiap daerah dieksplorasi dan dikembangkan. Untuk meningkatkan kemampuan di bidang teknik mikrovaskular, ahli bedah harus terus dilatih. Sebagai suatu teknik, bedah mikrovaskular menjadi semakin luas dan menjadi jelas bahwa teknik transfer ini 95-98\% dianggap handal dan hanya memerlukan 4-6 jam waktu operasi. ${ }^{15}$
Pemilihan eksisi luas dengan potong beku pada kasus ini untuk mengangkat seluruh massa tumor tanpa ada jaringan tumor yang tertinggal pada batas sayatan. Hal ini dilakukan untuk mencegah kemungkinan kekambuhan tumor. Dilanjutkan dengan radioterapi untuk menghindari kekambuhan pada basal sel karsinoma.

Jabir bebas melibatkan transplantasi jaringan menggunakan operasi mikrovaskuler. Transfer jaringan bebas mikrovaskuler adalah teknik rekonstruksi di mana unit jaringan terpisah dari suplai darah induk dan pindah dari satu bagian tubuh ke lokasi yang baru. Jaringan donor memiliki arteri dan vena yang diidentifikasi dapat direanastomosis dengan pembuluh penerima, sehingga membangun kembali aliran darah. Potensi reinnervation sensorik juga ada melalui reanastomosis saraf kulit.

Pemilihan jabir bebas dan jabir forehead paramedian sebagai tindakan penutupan defek karena teknik ini mempunyai beberapa keuntungan. Pertama, kaya akan vaskularisasi, yaitu berasal dari arteri supratroklearis dan cabang arteri dorsalis nasi, sehingga menjamin keberhasilan tandur. Kedua, teknik operasi sederhana sehingga mudah dilakukan. Ketiga, secara kosmetik lebih baik karena tidak melibatkan muskulus frontalis, sehingga pasca operasi tidak mengganggu ekpresi daerah dahi. ${ }^{15}$ Jabir bebas forearm menjadi pilihan pada kasus pasca radioterapi di mana vaskularisasi bagian distal sering terjadi kerusakan, dengan vaskularisasi yang baik akan memberikan suplai yang baik pada tandur.

Kesimpulan dari kasus ini adalah pemilihan jabir sebagai penutup defek merupakan alasan vaskularisasi yang buruk pada daerah resipien dan tidak mampu memberi asupan terhadap tandur yang ditransfer. Pada pasien ini, vaskularisasi daerah resipien kurang baik setelah radioterapi, sehingga dapat melindungi struktur vital tandur dengan re-anastomosis pembuluh darah. Jabir bebas tidak memiliki kendala anatomi dari sisi suplai pembuluh darah 
jabir, dan dapat dikerjakan dalam satu tahap, memungkinkan pendekatan dua tim secara bersamaan, dan memungkinkan ahli bedah reseksi untuk memperluas batas-batas organ yang akan direseksi.

\section{DAFTAR PUSTAKA}

1 Mathes SJ, Levine J. Muscle Flaps and Their Blood Supply. Dalam: Thorne C, Grabb WC, Smith JW, Beasley RW, penyunting. Grabb and Smith's Plastic Surgery.Edisi ke 6. Philadelphia: Wolters Kluwer Health/ Lippincott Williams \& Wilkins; 2007.

2. Lalwani A. Current Diagnosis \& Treatment Otolaryngology--Head and Neck Surgery.Edisi ke 3. New York: Mcgraw-hill; 2011.

3. Jewett B. Local Cutaneous Flaps and Graft. Dalam: Johnson JT, Rosen CA, Bailey BJ, penyunting. Bailey's Head and Neck Surgery - Otolaryngology.Edisi ke 5. Philadelphia: Wolters Kluwer Health/Lippincott Williams \& Wilkins; 2014.

4. Hatcher JL, Bell EB, Browne JD, Waltonen JD. Disposition of elderly patients after head and neck reconstruction. JAMA Otolaryngol Head Neck Surg. 2013;139(11):1236-41.

5. Trivedi NP, Trivedi P, Trivedi H, Trivedi S, Trivedi N. Microvascular free flapreconstruction for head and neck cancer in a resource-constrained environment in rural India. Indian J Plast Surg. 2013;46(1):82-6.

6. Tarsitano A, Pizzigallo A, Fantini MP, Marchetti C. Can microsurgical reconstruction after oral cancer improve patient-reported health-related quality of life? A 5-year experience. Journal of Medicine \& The Person. 2008;6(1):14-9.

7. Salvatori P, Paradisi S, Calabrese L, Zani A, Cantu G, Cappiello J, et al. Patients' survival after free flapreconstructive surgery of head and neck squamous cell carcinoma: a retrospective multicentre study. Acta Otorhinolaryngol Ital. 2014;34(2):99-104.
8. Adhistana P, Atmodiwirjo P. Microsurgery Reconstruction in Plastic Surgery Division FKUI - RSCM, From 2009 - 2010. Jurnal Plastik Rekonstruksi. 2012;1(2):135-42.

9. Girod DA, Tsue TT. Free Tissue Transfer. Dalam: Flint PW, Cummings CW, penyunting. Cummings Otolaryngology Head \& Neck Surgery.Edisi ke 5. Philadelphia: Mosby/ Elsevier; 2010.

10. Erovic BM, Lercher P. Manual of Head and Neck Reconstruction Using Regional and Flap bebass.Edisi ke 1. Verlag-Wien: Springer Vienna; 2014.

11. Hall JE. Guyton and Hall Textbook of Medical Physiology.Edisi ke 12. Elsevier Health Sciences; 2010.

12. Martini FH, Timmons MJ, Tallitsch RB. Human Anatomy. Edisi ke 7. New York: Benjamin-Cummings Publishing Company; 2011.

13. Brunicardi F, Andersen D, Billiar T, Dunn D, Hunter J, Matthews J, et al. Schwartz's Principles of Surgery, Ninth Edition.Edisi ke 8. New York: McGraw-Hill Education; 2009.

14. Chepeha DB. Microvascular Flap bebass in Head and Neck Reconstruction Dalam: Johnson JT, Rosen CA, Bailey BJ, penyunting. Bailey's Head and Neck Surgery - Otolaryngology.Edisi ke 5. Philadelphia: Wolters Kluwer Health/ Lippincott Williams \& Wilkins; 2014.

15. Yap LH, Butler CE. Principle of Microsurgery. Dalam: Thorne C, Grabb WC, Smith JW, Beasley RW, penyunting. Grabb and Smith's Plastic Surgery.Edisi ke 6. Philadelphia: Wolters Kluwer Health/Lippincott Williams \& Wilkins; 2007. 